\title{
High resolution temporal variation in wood properties in irrigated and non-irrigated Eucalyptus globulus
}

\author{
David M. DREW ${ }^{1 *}$, Geoffrey M. Downes ${ }^{2,3}$, Anthony P. O’GRADY ${ }^{4}$, Jennifer READ ${ }^{1}$, Dale WorLEDGE ${ }^{2,3}$ \\ ${ }^{1}$ Monash University, School of Biological Sciences (Building 18), Victoria 3800, Australia \\ Current address: CSIRO, Private Bag 12, 7001 Hobart Tasmania, Australia \\ ${ }^{2}$ CSIRO, Private Bag 12, 7001 Hobart Tasmania, Australia \\ ${ }^{3}$ Co-operative Research Centre for Forestry, Private Bag 12, 7001 Hobart Tasmania, Australia \\ ${ }^{4}$ University of Tasmania; School of Plant Science, Private Bag 55, 7001 Hobart Tasmania, Australia
}

(Received 12 September 2008; revised version 10 November 2008; accepted 12 December 2008)

Keywords:

xylem development /

dendrometers /

high resolution growth rates /

plant hydraulics
Mots-clés :

développement du xylème /

dendromètres /

taux de croissance à haute résolution /

hydraulique des plantes

\begin{abstract}
- Environmental determinants of wood properties variation were examined in Eucalyptus globulus, a globally important hardwood plantation species, in southern Tasmania, Australia.

- Radial variation in wood properties, measured with the SilviScan system, were re-scaled from distance to time abscissa using stem radial growth data measured with dendrometers. With this re-scaled data it was possible to evaluate how water availability and temperature affected wood density, microfibril angle (MFA) and fibre and vessel transverse dimensions in irrigated and non-irrigated trees. - Wood density, fibre radial diameter and MFA were sensitive to water availability. Wood density increased and fibre radial diameter decreased in response to reduced water availability. When high water availability was maintained, wood density was negatively correlated with temperature. Together, temperature and soil matric potential explained about $60 \%$ of temporal variation in wood density variation. In contrast MFA was not related to temperature but decreased with increasing water stress. Slower growing trees also had lower MFA than faster growing trees. Slower growing trees had a larger number of vessels per unit area of wood than faster growing trees within this even aged stand. However, vessel radius to the 4 th power was significantly higher in faster growing trees than in slower growing trees.

- Overall, E. globulus wood properties were sensitive to temporal changes in environmental conditions (particularly water availability) and associated growth rates. The data provided support for the hypothesis that growth rates are hydraulically mediated.
\end{abstract}

Résumé - Variations temporelles à haute résolution des propriétés du bois d'Eucalyptus globulus irrigués et non irrigués.

- Nous avons analysé les déterminants environnementaux des variations des propriétés du bois d'Eucalyptus globulus qui est une importante essence feuillue de plantation du sud de la Tasmanie en Australie.

- La variation radiale des propriétés du bois - mesurées avec l'outil Silviscan - a été convertie en variation temporelle par le biais des mesures de la croissance radiale obtenues avec des dendromètres. Avec ces données recalibrées il a été possible d'évaluer comment la disponibilité en eau et la température ont affecté la densité du bois, l'angle des microfibrilles ainsi que les dimensions transversale des fibres et vaisseaux pour les arbres irrigués et non irrigués.

- La densité du bois, le diamètre radial des fibres et l'angle des microfibrilles sont sensibles à la disponibilité en eau. En réponse à une réduction de la disponibilité en eau on observe que la densité du bois augmente et le diamètre radial des fibres diminue. Lorsqu'un niveau élevé de disponibilité en eau est maintenu alors la densité du bois apparaît négativement corrélée avec la température. La température et le potentiel matriciel du sol expliquent ensemble environ $60 \%$ de la variation temporelle de la densité du bois. À l'inverse l'angle des microfibrilles n'est pas relié à la température mais il décroît lorsque le stress hydrique augmente. Les arbres à croissance lente ont également un angle

\footnotetext{
* Corresponding author: david.drew@csiro.au
} 
des microfibrilles plus faible que les arbres à croissance rapide. Au sein des peuplements équiennes, les arbres à croissance lente on un plus grand nombre de vaisseaux par unité de surface du bois que les arbres à croissance plus rapide. Cependant la puissance quatrième du rayon des vaisseaux est significativement plus élevée pour les arbres à croissance rapide que pour les arbres à croissance lente.

- Dans l'ensemble les propriétés du bois d'E. globulus sont sensibles aux variations temporelles des conditions environnementales (en particulier la disponibilité en eau) et sont associées aux taux de croissance. Les données fournies confirment l'hypothèse que les taux de croissance sont régulés hydrauliquement.

\section{INTRODUCTION}

Eucalyptus globulus (Labill.) has become an important commercial forestry species worldwide, particularly for the production of pulp but also for the manufacture of other wood products. It is well established that the growth and functioning of $E$. globulus is sensitive to water availability (Drew et al., 2008; O'Grady et al., 2008). However the mechanisms linking wood properties to environmental factors such as temperature and water availability have not generally been well elucidated. Variation in wood properties is subject to genetic control, the environment in which the trees are grown, and to gene-byenvironment interactions (Zobel and Jett, 1995). Wood development processes are affected by the environment directly and indirectly via physiological responses in the cambial zone (Larson, 1994). Cambial responses and variations in wood properties are often difficult to interpret and generalise, due to the complexity and co-variance of factors involved in controlling xylem development, including tree hormonal balance, carbon fixation and allocation and tree water status (Chaffey, 2002).

The expansion of individual fibres and vessels requires that developing cells generate sufficient turgor and control the rheostatic properties of expansion in the cell wall, both of which will be impeded when hormonal balances change and water potential gradients across the developing xylem are steep (Cosgrove, 1986). When the processes of cell expansion and wall thickening are limited by water availability or other environmental factors, properties such as wood density and MFA may be markedly altered. In study of high resolution wood property variation in Picea abies, an increase in wood density occurred (creating a false ring) in association with increased drought stress (Bouriaud et al., 2005). Downes et al. (2004) and Wimmer et al. (2002) showed that wood density in $E$. nitens declined when water availability increased and Wimmer et al. (2002) demonstrated that MFA in Eucalyptus nitens (Deane and Maiden) increased when water stress was released. Drew and Pammenter (2007) observed increased cambial width and meristematic activity in relation to increased water availability in two sub-tropical hybrid Eucalyptus clones, highlighting the sensitivity of the mechanisms controlling wood properties development to water status.

Temperature may also play an important role in determining wood properties as growth rate and cambial activity are strongly regulated by temperature. Species from environments exhibiting large seasonality in temperature often have well defined annual growth rings and distinct variation in wood prop- erties (Sandercock et al., 1995). In eucalypts, however, the relationships between temperature and wood properties are more complex (Thomas et al., 2004). Downes et al. (2004) found that the correlation between temperature and wood properties such as wood density and MFA were poor, and recognized that such correlations can be easily confounded by other limiting factors, particularly water availability. However, temperature does significantly affect growth rates in eucalypts. Drew et al. (2008) and Wimmer et al. (2002) both demonstrated correlations between rates of stem increment and seasonal temperature. Drew et al. (2008) also found large variability in growth rates within an even aged E. globulus stand, where dominant trees had higher growth rates due to faster recovery from daily shrinkage events than suppressed trees, suggesting a hydraulically mediated constraint on stem growth. Thus unraveling the various controls on growth rates and the impact of these on resultant wood properties can be a complicated task (Thomas et al., 2004, 2006).

In order to develop an understanding of the causes of wood property variation, it is necessary to know when wood was formed to assess the effects of prevailing environmental conditions. Tree rings in the wood of E. globulus tend to be difficult to recognise, often not occurring on an annual basis (Leal et al., 2003). This has limited our ability to develop a mechanistic understanding of the processes driving wood formation and ultimately fibre properties. In this study we have rescaled wood properties data of irrigated and non-irrigated E. globulus trees from distance to time abscissa. The main goal of this approach was to unravel environmental controls on the development of wood properties. The aims of the study were to describe the effects of water availability and temperature on wood property variation over time. In addition, differences in average wood properties between slow- and fast-growing trees were examined to better understand the role of growth rates on wood properties variation.

\section{MATERIALS AND METHODS}

\subsection{Site description}

This research was conducted at the Pittwater research plantation, $20 \mathrm{~km}$ east of Hobart in south east Tasmania, Australia (42.8 S, 147.5 E, 9 mAMSL). The soil at the site has an aeolian-derived sandy A-horizon 1.5-2 m deep, overlaying a sandy-clay to clay B horizon. The depth to water table varies from $2-4 \mathrm{~m}$.

Climate for the region is classified as being cool temperate maritime. Rainfall in this region is usually evenly distributed throughout 
the year with an average of about $500 \mathrm{~mm}$ per year. Variation in the timing and amount of rainfall tends to be high, however. Total rainfall for the 23 months of the study was $783 \mathrm{~mm}$, which is substantially less than the long-term average rainfall for the site $\left(512 \mathrm{~mm} \cdot \mathrm{y}^{-1}\right.$ at Hobart airport, adjacent to the site). Pan evaporation rates are typically in excess of $1300 \mathrm{~mm}$ per year. Mean daily maximum and minimum temperatures vary between $22.5^{\circ} \mathrm{C}$ and $12.5^{\circ} \mathrm{C}$ and $12.0^{\circ} \mathrm{C}$ and $4.0^{\circ} \mathrm{C}$ for summer and winter respectively (Australian Bureau of Meteorology (BOM); URL: www.bom.gov.au).

The stand was established in September 2002 using E. globulus seedlings sourced from Gunns Woolnorth seedling orchard in NW Tasmania. Seedlings were on average $17 \mathrm{~cm}$ high and had a mean leaf area of $37 \mathrm{~cm}^{2}$ at the time of planting and were planted in nine growth plots each containing 25 trees, covering an area of $225 \mathrm{~m}^{2}$ at a spacing of $3 \mathrm{~m} \times 3 \mathrm{~m}$ (equivalent to 1111 stems ha $^{-1}$ ). The original experiment consisted of three water availability treatments arranged using a three-way Latin square (for details see O'Grady et al 2005). In the current study, results are only reported from two treatments; the rainfed ("non-irrigated") and the full irrigation ("irrigated") treatment. The rain-fed plots were not irrigated, except for the three months just following establishment, and trees were totally reliant on rainfall or soil water. In the irrigated plots, irrigation was applied to ensure a relatively uniform, non-limiting supply of water throughout the soil profile. An irrigation event equivalent to $6 \mathrm{~mm}$ of rainfall was applied every second night throughout the course of the experiment, except during winters of 2005 and 2006. In 2005, irrigation was switched off in early May and only restored in November, while in 2006 irrigation was turned off in May and restored in early July.

Granulated fertiliser was applied evenly across the site at a rate of $106 \mathrm{~kg} \mathrm{ha}^{-1} \mathrm{y}^{-1} \mathrm{~N}, 59 \mathrm{~kg} \mathrm{ha}^{-1} \mathrm{y}^{-1} \mathrm{P}$ and $60 \mathrm{~kg} \mathrm{ha}^{-1} \mathrm{y}^{-1} \mathrm{~K}$, also including a suite of trace elements (O'Grady et al., 2005). Manual and chemical weed control was maintained throughout the experiment.

\subsection{Weather and soil water data}

Weather at the site was monitored using an automatic weather station, installed approximately $100 \mathrm{~m} \mathrm{NE}$ of the plantation in an open field. Temperature and humidity were measured using a temperature/humidity probe (Vaisala HMP35A, Helsinki, Finland) mounted $1.5 \mathrm{~m}$ above ground level inside a Stevenson screen. Rainfall was measured using a tipping bucket rain gauge, $200 \mathrm{~mm}$ in diameter and $0.2 \mathrm{~mm}$ per tip (Monitor Sensors TBRG Qld, Australia). Total radiation was measured at $2 \mathrm{~m}$ above ground level using a Licor Li200x pyranometer (LiCor Biosciences, Nebraska, USA). Weather data were interrogated every minute. Vapour pressure deficit $(D)$ was calculated from relative humidity $\left(R_{\mathrm{H}}\right)$ and air temperature $\left(T_{\mathrm{A}}\right)$ (Goff and Gratch, 1946):

$$
\begin{aligned}
& V_{\mathrm{S}}=0.611 e^{\left(17.27 T_{\mathrm{A}} / T_{\mathrm{A}}+237\right)} \\
& D=\left(\left(\frac{R_{\mathrm{H}}}{100}\right) V_{\mathrm{S}}\right)-V_{\mathrm{S}},
\end{aligned}
$$

where $V_{\mathrm{S}}$ is saturated water vapour pressure $(\mathrm{kPa})$.

Daily temperatures at the research site reached a maximum of $37{ }^{\circ} \mathrm{C}$ and a minimum of $-2{ }^{\circ} \mathrm{C}$ during the study period. Maximum vapour pressure deficit $(D)$ achieved at the site was $4.7 \mathrm{kPa}$, and minimum $0.08 \mathrm{kPa}$.
Table I. Sample tree information. Tree "dominance classes" were determined by assessing stem DBH compared to the mean DBH in the experiment.

\begin{tabular}{lccc}
\hline Treatment & Dominance class & Tree number & DBH $(\mathrm{cm})$ \\
\hline & & 43 & 6.8 \\
& Suppressed & 83 & 9.2 \\
& & 184 & 8 \\
Irrigated & Average & 36 & 10.3 \\
& & 81 & 10.4 \\
& & 34 & 11.5 \\
& Dominant & 60 & 15.6 \\
& & 94 & 12.3 \\
& & 195 & 14.1 \\
& & 20 & 11.7 \\
\hline \multirow{4}{*}{ Suppressed } & 111 & 9.5 \\
& & 210 & 6.4 \\
& & 15 & 10.2 \\
& & 202 & 10.5 \\
& Average & 292 & 10.5 \\
& & 13 & 11.3 \\
& & 110 & 13.8 \\
& & 217 & 11.9 \\
& & 231 & 11.5 \\
\hline
\end{tabular}

\subsection{Soil and leaf water potential}

Soil moisture content has been monitored monthly at the site since establishment using a Neutron moisture meter (NMM probe Hydroprobe CPN503, ICT International, CA, USA). An access tube was installed in the middle of each plot and NMM counts were recorded at $15-20 \mathrm{~cm}$ intervals to approximately $2 \mathrm{~m}$ below ground level. Calibrations between relative water content (RWC) and NMM counts developed for soils at the site were used to convert counts to relative water content $\left(\mathrm{g} \cdot \mathrm{g}^{-1}\right)$. RWC was converted to matric potential based on soil water release curves developed for soils at the site.

Pre-dawn leaf water potential ( $\left.\Psi_{\text {leaf }}\right)$ was measured approximately monthly from November 2005 through to April 2006. For each tree, two leaves were sampled from the lower third of the canopy on the northern aspect. Leaves were immediately bagged and placed in a dark insulated container to prevent transpiration prior to measurement (Turner and Long, 1980) usually within 20 min of collection. Leaf water potential was measured using a Scholander type pressure chamber (PMS Instruments, Corvalis, USA).

\subsection{Monitoring tree growth}

Electronic point dendrometers (Agricultural Electronics Corporation (AEC), Tucson, Arizona USA) were used to measure stem size variation and growth. In July 2005, when the trees were 33 months old, 21 dendrometers were installed at breast height $(1.3 \mathrm{~m})$ on three trees per plot in six plots, selected using a stratified sampling approach. Selected trees were classified as "dominant", "average" and "suppressed" in each plot, based on their DBH relative to the DBH variation in the trial, at the time of installation (Tab. I). Dendrometers were mounted on $4 \mathrm{~mm}$ diameter stainless steel threaded rods inserted $40 \mathrm{~mm}$ into the wood. Each dendrometer sensing head was placed at the bark surface with loose bark removed. Dendrometers 
were calibrated so that a $4-\mu \mathrm{m}$ change in stem radius corresponded to approximately $1 \mathrm{mV}$. Radial stem size variation on the northern side of the tree was monitored at 15 min intervals. Data were collected for 23 months, until May 2007.

\subsection{Wood sampling and measurements}

In May 2007, a $12 \mathrm{~mm}$ diameter core was extracted from each study tree at the point at which the dendrometers were installed using a motorised corer. Cores were treated by replacing water with $100 \%$ ethanol in two stages, followed by air-drying (Downes et al., 1997). Samples were subsequently prepared for analysis using the Silviscan system (Evans, 1994; Evans et al., 1995). The samples were conditioned to $20^{\circ} \mathrm{C}$ and $40 \%$ relative humidity (RH). Thereafter, each core was cut using a specially designed saw so that the transverse surface was a strip $2 \mathrm{~mm}$ wide. Each strip was then polished by sanding with a sequence of graded sanding paper to provide a smooth surface and to maximise contrast between the cell lumen and wall. Samples were again conditioned to $20^{\circ} \mathrm{C}$ and $40 \% \mathrm{RH}$.

Wood density, microfibril angle (MFA), vessel and fibre size and vessel frequency were measured along pith-to-bark wood strips using SilviScan at a radial resolution of $100 \mu \mathrm{m}$. Isopycnic angles, which were considered to approximate the ray angle in these trees, were determined for a single sample, which was then used to generate appropriate corrections for the calculation of density and MFA in SilviScan for all samples. The detection and the calculation of vessel dimensions in the SilviScan system is potentially biased towards the detection of larger vessels and this can lead to an overestimate in some cases. Care was taken to minimize this effect in the measurement and analyses of vessel dimensions in this study.

\subsection{Re-scaling wood properties data}

When radial stem growth is measured along the same radius from which a wood sample is subsequently taken, it is possible to infer the approximate date of formation of particular radial portions of wood; the wood data (SilviScan profile) and the radial growth data share the axis "distance from bark" (or from pith). This approach, described in Downes et al (2004), and used in a small number of studies, such as Wimmer et al. (2002) and Bouriaud et al. (2005), is discussed in more detail in a recent review by Drew and Downes (2009). For this study, stem radius as measured by dendrometers was corrected for changes in bark and phloem thickness using a value proportionate to stem size in each tree. The calculation assumed a constant rate of bark and phloem production. Net shrinkage that occurred over a period of more than one day was assumed to be zero growth (i.e. no wood was formed). The conditions that prevailed before and when this wood formed can be related to the properties of the wood by rescaling the wood onto a time axis after allowing for differences arising from bark and/or phloem production.

\subsection{Calculations and data analysis}

Statistical analyses were undertaken using SPSS 15 for Microsoft Windows (SPSS Inc.). For overall effects between treatments, a $t$ test was used. When considering effects over time or assessing treatment differences over specific periods, ANOVA of wood properties was conducted using general linear models (GLM) repeated measures analysis. Generally, DBH and growth rates did not significantly improve model estimates and thus were not considered as covariates in the analyses unless specifically mentioned in the text. When significance is quoted for differences over time, it is calculated with degrees of freedom modified using the Huynh-Feldt statistic, under the assumption that sphericity could not be assumed to be true. Correlations were calculated between monthly means of environmental variables and average properties of wood formed over that month using least squares linear regression and multiple regression analysis.

When lags were considered, it was only for one month, so that, for example, the average density of wood formed this month was compared with the average temperature last month. Average daily rates of fibre production were calculated by dividing the average daily stem growth for each month for each tree by the average radial diameter of the fibres formed over that month. Weighted mean wood density (WMD) was calculated by assigning a factor calculated from the relative cross sectional stem area of wood formed in each radial increment to the wood density measured by SilviScan in of these increments (the larger the area, the higher the contribution of a particular radial segment of wood to overall wood density). For analyses of vessel size and its effects on overall conductivity, vessel radial diameter is raised to the fourth power (Zimmerman, 1983). For the analysis of the effect of growth rate, the irrigation treatments were ignored, and two growth rate classes were developed only on the basis of growth rate during the study. Seven trees were allocated to each class (14 in total). Trees whose total radial growth over the study period was less than $21 \mathrm{~mm}$ were classed as "slow growing" while trees whose growth was greater than $31 \mathrm{~mm}$ were classed as "fast growing". A total of 14 trees were used for these "growth rate class" analyses.

\section{RESULTS}

\subsection{Stem growth and fibre production rates}

At the start of the study, the average DBH of the trees monitored in the irrigated plots were not significantly higher than in the non-irrigated plots $(t=0.795 ; p=0.439)$. There was also no difference in the total growth of the trees in the two treatments from August 2005 to May $2007(t=0.638 ; p=0.532)$. During the period May to July 2006, however, when irrigation was temporarily stopped, soil matric potential in the first metre of soil dropped markedly in the previously irrigated plots, resulting in increased water stress in those trees. Over this period, pre-dawn leaf water potential reached a minimum of $-1.3 \mathrm{MPa}$ in some trees and the growth increment was significantly $(t=3.07 ; p=0.003)$ lower in the irrigated trees than in the non-irrigated trees (Fig. 1). The non-irrigated trees also had fibre production rates 1.5 times higher in May and June 2006 than the previously irrigated trees $(F=5.0 ; p=0.040)$ (Fig. 2). The higher fibre production rates observed in the nonirrigated trees compared to the irrigated trees from November 2006 to February 2007 (Fig. 2) were associated with smaller amounts of daily stem shrinkage, indicating higher levels of diurnally varying drought stress, in the latter treatment. Similarly, the non-irrigated trees were able to spend longer each day in the phase of stem increment from November 2006 to February 2007 than the irrigated trees. 


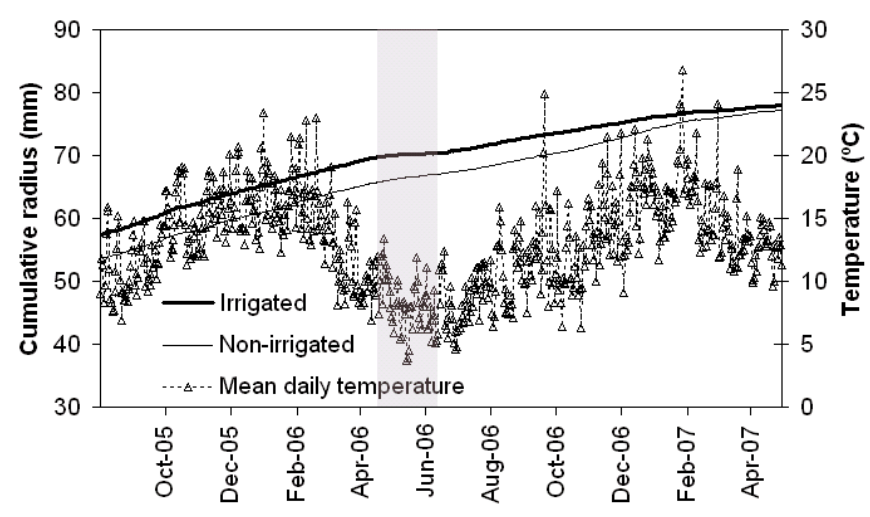

Figure 1. Daily average cumulative stem radius in the irrigated and non-irrigated trees and average daily temperature at the study site from late-July 2005 to May 2007. The shaded area indicates the period (May to July 2006) during which irrigation was temporarily discontinued in the irrigated treatment, and when the change in stem radius was markedly reduced in those trees.

\subsection{Wood density}

There was no overall difference in weighted mean wood density (WMD) between the irrigated and non-irrigated trees $(t=0.539 ; p=0.598)$ or between the average wood density of slow-growing and fast-growing trees $(t=0.841 ; p=0.416)$. In both treatments, however, there was significant $(F=11.3$; $p<0.001$ ) month by month variation in density. Over the study period, average wood density of individual trees varied by more than $600 \mathrm{~kg} \mathrm{~m}^{-3}$, between $320 \mathrm{~kg} \mathrm{~m}^{-3}$ and $960 \mathrm{~kg}$ $\mathrm{m}^{-3}$ in both treatments.

In the non-irrigated trees, wood density increased markedly in January 2006 as soil matric potential dropped suddenly (Figs. 3a and 3b). Average density remained high until approximately July, after which it declined significantly until the end of the study period $(F=10.4 ; p=0.006)$. Although, overall, wood density did not differ between treatments or between slower and faster-growing trees, the density of the wood formed by the previously irrigated trees was significantly $(F=$ $10.1 ; p=0.006$ ) higher than the wood formed by the nonirrigated trees in June and July 2006.

\subsection{Microfibril angle}

There was no difference in average microfibril angle (MFA) between irrigated and non-irrigated trees $(t=1.015 ; p=$ $0.323)$, but MFA was significantly $(t=2.6 ; p=0.020)$ lower in slow-growing trees $\left(9.9^{\circ} \pm 0.7\right)$ than in fast-growing trees $\left(11.0^{\circ} \pm 0.6\right)$. MFA varied between about $7^{\circ}$ and $17^{\circ}$ during the study period, during which there was significant $(F=14.5$; $p<0.001)$ month by month variation, with a distinct reduction in MFA occurring over the period May to July 2006 in trees where irrigation was temporarily discontinued (Fig. 3c). This drop in average MFA was caused by a reduction in MFA variation, with no trees producing MFA over $10.3^{\circ}$. In the irrigated treatment, MFA also varied significantly $(F=6.4 ; p=0.045)$ by the interaction; growth rate class and month. That is, the effect of environmental variation on MFA variation was not the same in fast and slow growing trees over time. In both treatments there was an overall decline in average MFA over the study period $(F=51.8 ; p<0.001)$.

\subsection{Fibre radial diameter}

The mean fibre radial diameter of the irrigated trees $(13.4 \mu \mathrm{m} \pm 0.4)$ was higher than in the non-irrigated trees $(12.9 \mu \mathrm{m} \pm 0.18)(t=2.04 ; p=0.060)$ but there was no difference between mean fibre radial diameter in fast- compared with slow-growing trees $(t=0.586 ; p=0.570)$. Fibre radial diameter varied between approximately $10 \mu \mathrm{m}$ and $17 \mu \mathrm{m}$ during the study period (Fig. 3d). The diameter of fibres formed in the summer of 2006 in the non-irrigated trees dropped as a result of the low soil matric potential in January, while in the irrigated trees the sudden drop in soil matric potential in winter 2006 (due to cessation of irrigation) caused a rapid decline in fibre radial diameter (Fig. 3d). From November 2006 to February 2007, when fibre production rates were highest in the non-irrigated trees, fibre radial diameter was significantly higher $(t=2.314 ; p=0.039)$ in the irrigated trees than in the non-irrigated trees.

\subsection{Vessel size and frequency}

There was no difference between the average vessel size $(t=0.739 ; p=0.471)$ or vessel frequency $(t=0.445 ; p=$ 0.662 ) in irrigated and non-irrigated trees over the study period. However, the fourth power of vessel radius was higher in faster-growing $\left(20.8 \pm 4.5 \times 10^{6} \mu^{4}\right)$ than in slower-growing trees $\left(12.3 \pm 3.0 \times 10^{6} \mu \mathrm{m}^{4}\right)(t=2.05 ; p=0.060)$. The fast growing trees produced fewer vessels per unit wood area $\left(5.2 \pm 0.6\right.$ vessels $\left.\mathrm{mm}^{-2}\right)$ than the slow growing trees $(6.4 \pm$ 0.5 vessels $\left.\mathrm{mm}^{-2}\right)(t=3.5 ; p=0.004)$. Overall, therefore, there was no difference in the average vessel area per unit cross sectional area of wood between fast growing and slow growing trees $(t=0.963 ; p=0.356)$.

\subsection{Environment, growth and wood property relationships}

The average density of wood formed each month was most strongly correlated with mean temperature of that month (Tab. II). Average density of wood formed each month was explained by a linear model using soil matric potential (significant at $\alpha=0.05$ in both treatments) and mean monthly temperature (significant at $\alpha=0.05$ in both treatments). More than $65 \%(r=0.81 ; p<0.001)$ and $59 \%(r=0.77 ; p=0.001)$ of the variation was explained by the model in irrigated and non-irrigated trees, respectively. Using rainfall in the models did not improve the prediction significantly. There was also a significant correlation between average daily stem growth rate and MFA in both treatments, but not with wood density (Tab. II). Fibre radial diameter was significantly correlated with soil matric potential in both treatments (Tab. II). 


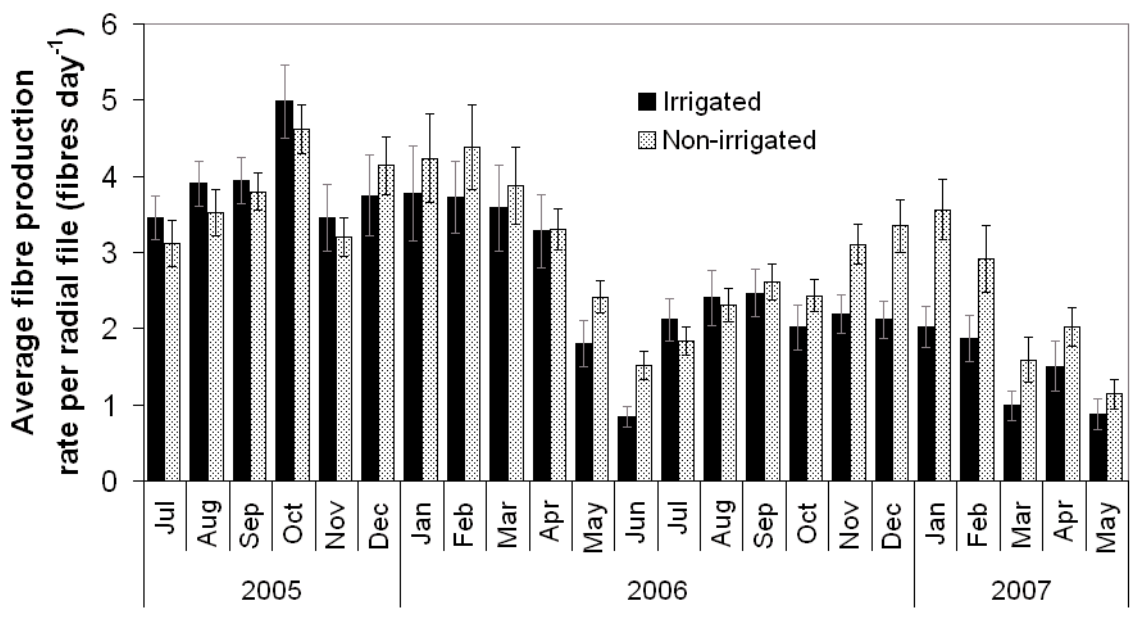

Figure 2. Monthly averaged daily rates of fibre production per radial cell file in the irrigated and non-irrigated trees from July 2005 to May 2007. Bars show mean \pm standard error.

\section{DISCUSSION}

The re-scaling of wood properties data from distance to time abscissa was a fundamental part of this research and is of particular importance in species such as Eucalyptus, where tree rings are typically not formed annually and have little use in dating wood (Leal et al., 2003). The re-scaling in this study was achieved using high resolution stem growth data (daily averaged measurements). However, the resolution at which it is possible to re-scale wood properties does not necessarily need to be so precise. It is possible to achieve equally successful re-scaling even when measuring stem growth lower temporal resolution than daily (e.g. Watt et al. (2005), who measured growth monthly). Actual cell production and irreversible expansion can be considered "real growth", but this is not all that is measured by a dendrometer positioned against a tree stem. The resolution of the re-scaling approach is limited by more than one source of stem size variation. First, daily stem expansion consists partly of a hydration event which, although most likely associated with actual wood production, does not consist entirely thereof. Second, although corrections were made in this study for changes in bark thickness, a certain ambiguity in the re-scaling process will also result from this change in tissue width external to the xylem.

Therefore, the approach taken here is designed as a means of obtaining an approximation of the date of formation of successive wood segments for each tree, acknowledging the errors introduced from daily stem hydration and changes in bark thickness. It is assumed, however, that when averaging over multiple trees, the ability to detect responses over relatively short period (in the order of a few days, rather than a single day) is reasonable, and can provide robust insights. It also has the advantage of providing concomitant high resolution information on stem size variation, which can be useful in gaining insight into continuous changes in cambial activity (Deslauriers et al., 2007). As such, if the inherent errors in the approach are acknowledged, and inferences made at a realistic level of precision, the technique can be considered of great use in trees where no clear growth rings are produced.

\subsection{The effect of the onset of drought on wood property variation}

Because the site had a relatively shallow water table, the non-irrigated trees did not show signs of severe drought stress during the study period. Furthermore, the irrigation treatments had little effect on either overall stem growth or wood property variation. There was evidence that the irrigated trees maintained a higher fibre radial diameter than the non-irrigated trees, and fibre radial diameter declined in the non-irrigated trees in the summer of 2006 when temperatures and humidity were high. However, it was during the period when irrigation was discontinued that the largest differences were observed in both stem growth rates (Drew et al., 2008) and wood properties between the two treatments.

The trees growing under the different irrigation treatments can be expected to have employed different physiological and morphological strategies to cope with their particular water availability regimes. Irrigated trees in this study maintained higher canopy conductance (O'Grady et al., 2008) and most likely had shallower root systems (Moroni et al., 2003), making them more vulnerable to drought than the non-irrigated trees. Over the winter period, when irrigation was temporarily discontinued, trees in the irrigated treatments exhibited marked declines in leaf water potential (Drew et al., 2008) and significant reductions in growth rates, or no growth at all. In contrast, trees in the non-irrigated treatments, showed little change in growth rate over this period. On several occasions during this period, the previously irrigated trees experienced a net shrinkage over a number of days, as the stems were unable to expand during the night-time recovery period to reach the previous maximum diameter (Drew et al., 2008) 

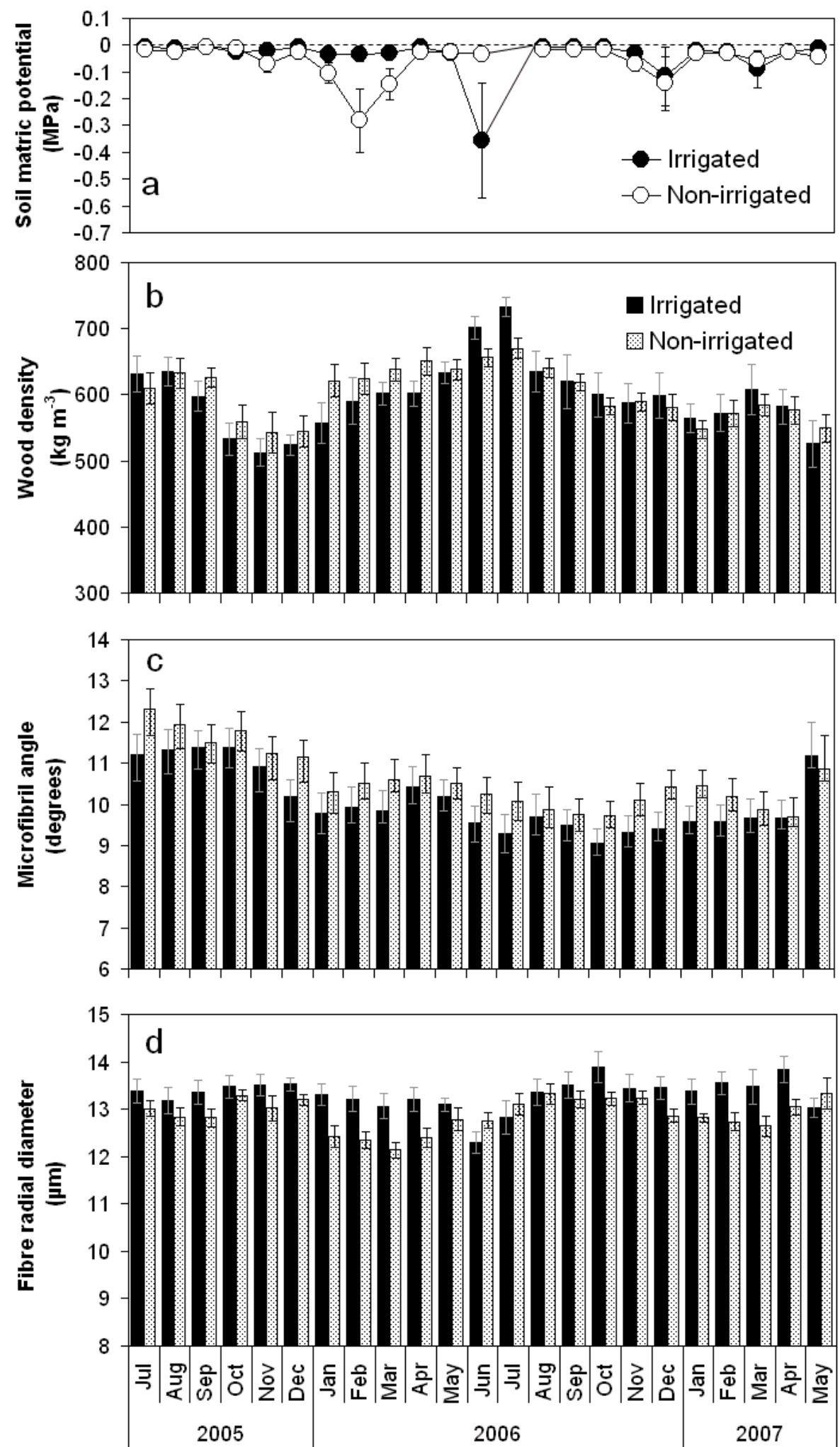

Figure 3. Monthly averaged soil matric potential and re-scaled average wood properties in the irrigated and non-irrigated plots from July 2005 to May 2007. Soil matric potential reached a minimum in summer 2006 in the non-irrigated trees and in winter 2006 in the irrigated trees (a). Wood density increased in response to high water deficits in non-irrigated trees in summer 2006 and in irrigated trees in winter 2006 (b). Microfibril angle declined in winter 2006 in irrigated trees and increased in late 2006/early 2007 in non-irrigated trees (c). Fibre radial diameter decreased in non-irrigated trees in summer 2006 and in irrigated trees in winter 2006 (d). Bars/points show mean \pm standard error. 
Table II. Spearman rank correlation matrix for monthly averaged wood properties and monthly averaged or summed environmental variables.

\begin{tabular}{|c|c|c|c|c|c|}
\hline Treatment & Independent variable & Wood density & MFA & Fibre radial diameter & Vessel transverse area \\
\hline \multirow{10}{*}{ Irrigated } & Average soil matric potential & 0.11 & -0.37 & $-0.45 *$ & $-0.60 * *$ \\
\hline & Average soil matric potential (lagged) & 0.22 & $-0.45 *$ & -0.43 & -0.12 \\
\hline & Total rainfall & -0.35 & 0.08 & 0.23 & 0.01 \\
\hline & Total rainfall (lagged) & $-0.59 * *$ & 0.34 & 0.40 & -0.20 \\
\hline & Average temperature & $-0.76 * *$ & -0.04 & 0.11 & -0.31 \\
\hline & Average temperature (lagged) & $-0.56 * *$ & -0.01 & 0.07 & -0.34 \\
\hline & Average net daily stem growth & -0.03 & $0.60 * *$ & 0.32 & 0.38 \\
\hline & Average net daily stem growth (lagged) & -0.13 & $0.62 * *$ & 0.19 & 0.17 \\
\hline & Total solar radiation & $-0.60 * *$ & -0.17 & $0.41 *$ & -0.04 \\
\hline & Total solar radiation (lagged) & $-0.61 * *$ & -0.12 & 0.14 & -0.27 \\
\hline \multirow{10}{*}{ Non-irrigated } & Average soil matric potential & -0.02 & -0.12 & $-0.55 *$ & -0.41 \\
\hline & Average soil matric potential (lagged) & 0.21 & -0.04 & $-0.60 * *$ & $-0.48 *$ \\
\hline & Total rainfall & $-0.42 *$ & 0.31 & 0.18 & 0.25 \\
\hline & Total rainfall (lagged) & $-0.60 * *$ & 0.17 & 0.12 & -0.09 \\
\hline & Average temperature & $-0.69 * *$ & -0.14 & -0.19 & -0.31 \\
\hline & Average temperature (lagged) & -0.41 & -0.21 & $-0.50 *$ & $-0.70 * *$ \\
\hline & Average net daily stem growth & -0.19 & $0.54 * *$ & -0.08 & -0.12 \\
\hline & Average net daily stem growth (lagged) & -0.14 & $0.51 *$ & $-0.45^{*}$ & -0.34 \\
\hline & Total solar radiation & $-0.59 * *$ & -0.20 & 0.00 & 0.07 \\
\hline & Total solar radiation (lagged) & $-0.56 * *$ & -0.11 & -0.32 & -0.39 \\
\hline
\end{tabular}

* Significant at $p<0.05 ; * *$ significant at $p<0.01 ; N=20-23$.

and it is likely that the cambial zone would have become inactive at this time, even exhibiting signs of dormancy (Drew and Pammenter, 2007).

Xylem water potential is often the most critical determinant of cell growth in the cambial zone (Kozlowski et al., 1991). Thus as soil matric potential and leaf water potential declined, radial cell growth in the zone of enlargement was impeded. Accordingly, fibre radial diameter was reduced by more than $8 \%$ from pre-May values when irrigation ceased. In the nonirrigated trees, fibre diameter was 12\% lower in February 2006 (when temperature and vapour pressure deficit peaked at the site) than the maximum fibre diameter measured in November 2005 . In both cases these smaller fibres contributed to significant increases in wood density. However, provided severe damage is not done to living cells, an increase in water availability following a period of drought will quickly result in the resumption of cell radial expansion. In this study it was evident that E. globulus trees can respond rapidly to changing conditions. The increment phase of the daily pattern of stem size variation became evident again as soon as irrigation was resumed (Drew et al., 2008). Concurrently, fibre radial diameter in the wood increased, and wood density decreased. Enhanced fibre expansion does not always relate to rates of fibre production, however. From November 2006 to February 2007, although the non-irrigated trees had smaller fibres than the irrigated trees, they produced significantly more fibres. Although irrigation was being maintained at the time, soil matric potential declined in November and December 2006 in both irrigated and non-irrigated treatments. In addition, stem shrinkage was higher in irrigated trees than in non-irrigated trees, indicating higher levels of drought stress in the former case, even with regular irrigation. This suggests that under these conditions, the irrigated trees were allocating water resources to growing larger fibres as opposed to producing greater numbers of fibres. This was opposite to the strategy employed by the non-irrigated trees, in which daily stem shrinkage, and probably levels of drought stress, were less marked.

MFA showed a distinct decrease over the period May to July 2006 in the irrigated trees, and in late January in the non-irrigated trees, in both cases as a function of the direct and indirect effects of drought stress, similar to findings in E. nitens (Wimmer et al., 2002). Previous research strongly suggests that the orientation of microfibrils in the primary and secondary cell wall is controlled by microtubule arrays (Qiu et al., 2008), likely in conjunction with complex interactions with scaffold proteins (Mellerowicz and Sundberg, 2008). If the microtubule-microfibril interaction determines MFA, the change in orientation of MFA in the secondary wall is likely also due to changes in the arrangement of microtubule arrays known to occur radially and seasonally in the cambium (Chaffey et al., 1998). The reduction in the angle of the microfibrils is probably driven by the influence of internal and external stimuli on MT orientation (Schopfer, 2006), including temperature, osmotic and drought stress and the related action of hormones like ethylene and abscisic acid (ABA) (Wasteneys, 2004).

\subsection{Density and MFA models based on temperature and soil water content}

Overall, variation in wood density at this site over the two years of the study was driven predominantly by two environmental variables, temperature and soil moisture availability. Microfibril angle, on the other hand, correlated strongly with soil matric potential, but not with temperature. There was also 
a significant correlation between MFA and stem growth rates, which is not unexpected since high MFA is typically associated with juvenile wood, compared to mature wood when growth rates are slower, and early wood, compared to latewood where, again, growth rates are slower (Barnett and Bonham, 2004).

\subsection{Wood properties in slow and fast growing trees}

In the present study, fast growing trees had fewer and larger vessels than slow growing trees. These results add credence to the hypothesis presented by Tyree (2003) that smaller, slowergrowing ("suppressed") trees have lower overall water conductivity, thus taking longer to recover from low water potential each day, and reducing growth overall (Drew et al., 2008). There was no evidence of any difference in wood density or fibre radial diameter between slow and fast growing trees, however.

Microfibril angle was lower in slow growing trees than in fast growing trees. This contrasts with findings of Wimmer et al. (2008) who reported higher average MFA at slowgrowing compared to fast-growing E. globulus sites in Tasmania. In that study, the difference was probably a function of earlywood/latewood effects. The poor site was particularly dry in summer, so that the wood was dominated by high MFA spring-formed wood. In contrast, the high potential site experienced better summer-autumn rainfall, and produced lower MFA latewood. This emphasizes the complexity in generalisations of the environment vs. MFA relationship and the need for further research.

\section{CONCLUSIONS}

In this study, insights into the effects of changing environmental conditions on wood properties in E. globulus were possible because of the use of stem growth data to "re-scale" the wood properties data. Decreased water availability resulted in marked increases in wood density and decreases in fibre radial diameter. When water availability was not limiting, wood density in E. globulus was positively correlated with temperature. Microfibril angle (MFA) was not affected by temperature, but was driven mainly by fluctuations in site water availability. Reduced water availability resulted in reduced MFA, probably modulated by changes in growth rate, with lower MFA generally occurring in slower growing trees. Slower growing trees had a larger number of vessels per unit area but the average vessel diameter (to the fourth power) was lower than in faster growing trees providing support for the Tyree (2003) hypothesis that high conductance is necessary for maintaining high growth rates.

Acknowledgements: The authors would like to thank Charles and Robin Lewis of Milford Farm for their continued support of the research at the Pittwater research site. A.P. O'Grady was funded by an ARC Linkage grant (LP0454287) and D. Drew was funded partly by Monash Research Graduate School (MRGS). Grateful thanks to
Dr. Rob Evans for his assistance with the processing of the SilviScan data and Ms. Sharee Harper and Mr David Menz for help in sample processing. Also thanks to Dr. Michael Battaglia and Dr Patrick Baker for their support, and to the anonymous reviewers for helpful and constructive comments and suggestions.

\section{REFERENCES}

Barnett J.R. and Bonham V.A., 2004. Cellulose microfibril angle in the cell wall of wood fibres. Biol. Rev. 79: 461-472.

Bouriaud O., Leban J.-M., Bert D., and Deleuze C., 2005. Intra-annual variations in climate influence growth and wood density of Norway spruce. Tree Physiol. 25: 651-660.

Chaffey N., 2002. Why is there so little research into the cell biology of the secondary vascular system of trees? New Phytol. 153: 213-223.

Chaffey N., Barlow P.W., and Barnett J.R., 1998. A seasonal cycle of cell wall structure is accompanied by a cyclical rearrangement of cortical microtubules in fusiform cambial cells within taproots of Aesculus hippocastanum. New Phytol. 139: 623-635.

Cosgrove D.J., 1986. Biophysical control of plant cell growth. Annu. Rev. Plant Physiol. 37: 377-405.

Deslauriers A., Anfodillo T., Rossi S., and Carraro V., 2007. Using simple causal modeling to understand how water and temperature affect daily stem radial variation in trees. Tree Physiol. 27: 1125-1136.

Downes G.M., Hudson I., Raymond C.A., Dean G.H., Michell A.J., Schimleck L.R., Evans R., and Muneri A., 1997. Sampling plantation eucalypts for wood and fibre properties, CSIRO Publishing, Melbourne.

Downes G.M., Wimmer R., and Evans R., 2004. Interpreting sub-annual wood property variation in terms of stem growth, in: Schmitt U., Ander P., Barnett J.R., Emons A.M.C., Jeronimidis G., Saranpaä P., and Tschegg S. (Eds.), Wood fibre cell walls: methods to study their formation, structure and properties, Swedish university of Agr. sciences, Dept. of Wood Science, pp. 267-283.

Drew D.M. and Downes G.M., 2009. The use of precision dendrometers in research on daily stem size and wood property variation: a review. Dendrochronologia (in Press).

Drew D.M., O'Grady A.P., Downes G.M., Read J., and Worledge D., 2008. Daily patterns of stem size variation in irrigated and nonirrigated Eucalyptus globulus Tree Physiol. 28: 1573-1581.

Drew D.M. and Pammenter N.W., 2007. Developmental rates and morphological properties of fibres in two eucalypt clones at sites differing in water availability. Southern Hemisphere Foresty Journal 69: $71-79$.

Evans R., 1994. Rapid measurement of the transverse dimensions of tracheids in radial wood sections from Pinus radiata. Holzforschung 48: $168-172$.

Evans R., Downes G.M., Menz D., and Stringer S., 1995. Rapid measurement of variation in tracheid transverse dimensions in a radiata pine. Appita J. 48: 134-138.

Goff G.A. and Gratch S., 1946. Smithsonian meteorological tables. Trans. Am. Soc. Ventilation Eng. 52: 95.

Kozlowski T.T., Kramer P.J., and Pallardy S.G., 1991. The physiological ecology of woody plants, Academic press, San Diego.

Larson P., 1994. The vascular cambium: development and structure, Springer-Verlag, New York.

Leal S., Pereira H., Grabner M., and Wimmer R., 2003. Clonal and site variation of vessels in 7-year-old Eucalyptus globulus. IAWA J. 24: 185-195. 
Mellerowicz E.J. and Sundberg B., 2008. Wood cell walls: biosynthesis, developmental dynamics and their implications for wood properties. Curr. Opin. Plant Biol. 11: 293-300.

Moroni M.T., Worledge D., and Beadle C.L., 2003. Root distribution of Eucalyptus nitens and E. globulus in irrigated and droughted soil. For. Ecol. Manage. 177: 399-407.

O'Grady A.P., Worledge D., and Battaglia M., 2005. Temporal and spatial changes in fine root distributions in a young Eucalyptus globulus stand in southern Tasmania. For. Ecol. Manage. 214: 373-383.

O’Grady A.P., Worledge D., and Battaglia M., 2008. Constraints on transpiration of Eucalyptus globulus in southern Tasmania, Australia. Agric. For. Meteorol. 148: 453-465.

Qiu D., Wilson I.W., Gan S., Washusen R., Moran G.F., and Southerton S.G., 2008. Gene expression in Eucalyptus branch wood with marked variation in cellulose microfibril orientation and lacking G-layers. New Phytol. 179: 94-103.

Schopfer P., 2006. Biomechanics of plant growth. Am. J. Bot. 93: 14151425.

Thomas D.S., Montagu K.D., and Conroy J.P., 2004. Changes in wood density of Eucalyptus camaldulensis due to temperature - the physiological link between water viscosity and wood anatomy. For. Ecol. Manage. 193: 157-165.

Thomas D.S., Montagu K.D., and Conroy J.P., 2006. Effects of leaf and branch removal on carbon assimilation and stem wood density of Eucalyptus grandis seedlings. Trees 20: 725-733.
Turner N.C. and Long M.J., 1980. Errors arising from rapid water loss in the measurement of leaf water potential by the pressure chamber technique. Aust. J. Plant Physiol. 7: 527-537.

Tyree M.T., 2003. Hydraulic limits on tree performance: transpiration, carbon gain and growth of trees. Trees 17: 95-100.

Wasteneys G.O., 2004. Progress in understanding the role of microtubules in plant cells. Curr. Opin. Plant Biol. 7: 651-660.

Watt M.S., Downes G.M., Whitehead D., Mason E.G., Richardson B., Grace J.C., and Moore J.R., 2005. Wood properties of juvenile Pinus radiata growing in the presence and absence of competing understorey vegetation at a dryland site. Trees 19: 580-586.

Wimmer R., Downes G., Evans R., and French J., 2008. Effects of site on fibre, kraft and handsheet properties of Eucalyptus globulus. Ann. For. Sci. 65: 602.

Wimmer R., Downes G.M., and Evans R., 2002a. High-resolution analysis of radial growth and wood density in Eucalyptus nitens, grown under different irrigation regimes. Ann. For. Sci. 59: 519-524.

Wimmer R., Downes G.M., and Evans R., 2002b. Temporal variation of microfibril angle in Eucalyptus nitens grown in different irrigation regimes. Tree Physiol. 22: 449-457.

Zimmerman M.H., 1983. Xylem structure and the ascent of sap, SpringerVerlag, Berlin.

Zobel B.J. and Jett J.B., 1995. Genetics of wood production, SpringerVerlag, Berlin. 